PODMIOTY UDZIELAJĄCE POŻYCZKI POZA BANKOWE W POLSCE W KONTEKŚCIE PRAWNYCH OGRANICZEŃ DZIAŁALNOŚCI NAKLADANYCH NA MAKSYMALNE POZIOMY POBIERANYCH PROWIZJI

\title{
THE NON-BANKING LENDING MARKET IN POLAND IN THE CONTEXT OF THE LEGAL LIMITATIONS IMPOSED ON THE LEVEL OF MAXIMUM POSSIBLE COMMISSIONS
}

\author{
Lech KOŚCIELECKI \\ Lech.Koscielecki@wat.edu.pl \\ Michał PAPLIŃSKI \\ MichalPapl@gmail.com \\ Wojskowa Akademia Techniczna \\ Wydział Logistyki \\ Instytut Logistyki
}

\begin{abstract}
Streszczenie: Celem tego artykułu jest zaprezentowanie znaczenia rynku pożyczek poza bankowych w polskiej gospodarce, ograniczeń prawnych nakładanych na podmioty działajace zgodnie z ustawa o kredycie konsumenckim oraz kreatywnych sposobów, w jaki spótki udzielajace pożyczki poza bankowe, pomimo restrykcyjnych przepisów prawa polskiego, generuja zyski. W artykule przedstawiono najpopularniejsze, stosowane przez spótki pożyczkowe rozwiązania pozwalajace być w zgodzie z prawem polskim (często dziatając na granicy prawa), a zarazem maksymalizujace zysk tj. refinansowanie netto i refinansowanie brutto.

Abstract: The purpose of this article is to present the significance of the non-banking lending market in the Polish economy, the legal constraints imposed on entities operating under the consumer credit law, and the creative ways in which non-bank loan companies, despite restrictive Polish law, generate profits. The article presents the most popular solutions applied by the loan companies, which allow them to be compliant with the Polish law (often acting on the law border), while maximizing profit which are net refinancing and gross refinancing.

Stowa kluczowe: sektor pożyczkowy, prowizje, ograniczenia prawne

Key words: lending market, commissions, legal restrictions
\end{abstract}

\section{WSTEPP}

Możliwość pozyskania finansowania przez spółki oraz gospodarstwa domowe w celu realizacji inwestycji bądź indywidualnych planów zwiększa poczucie bezpieczeństwa finansowego tychże podmiotów.

$\mathrm{Na}$ rynku polskim finansowanie można pozyskać przede wszystkim od banków, spółdzielczych kas oszczędnościowych i firm pożyczkowych. Na koniec 2014 roku oraz 2015 roku banki posiadały portfel kredytów udzielonych gospodarstwom domowym w wysokości 585,9 mld zł oraz 624,5 mld zł o odpowiednio, z czego 61,1\% stanowiły kredyty mieszkaniowe, $21,8 \%$ kredyty konsumpcyjne oraz $17,1 \%$ kredyty pozostałe 
(https://www.knf.gov.pl). Dla porównania, spółki pożyczkowe na koniec 2014 roku udzieliły 4,5 mld zł pożyczek oraz 5,4 mld zł na koniec 2015 roku.

W celu zapewnienia porównywalności danych z perspektywy celu zaciągnięcia zadłużenia, należy porównywać jedynie kredyty konsumpcyjne zaciągnięte w bankach wraz z pożyczkami z rynku poza bankowego. Z tej perspektywy sektor poza bankowy stanowi około 4,0\% wszystkich środków udzielonych klientom (Stańczyk, 2016).

\section{SPECYFIKA RYNKU POŻYCZEK POZA BANKOWYCH W POLSCE}

Rynek pożyczek poza bankowych w Polsce wykazuje stałą tendencję wzrostową od 2010 roku, zarówno pod względem wartości udzielonych pożyczek jak również portfela pożyczek na koniec każdego roku.

Spółki pożyczkowe udzieliły w 2008 roku 1,9 mld zł pożyczek i do 2010 roku wartość ta utrzymywała się na zbliżonym poziomie. W 2012 roku spółki pożyczkowe udzieliły 2,3 mld zł, a w 2016 roku już 6,0 miliarda złotych odnotowując 260,9\% wzrostu w ciągu 4 lat (Waściński, Dudkowska, 2017).

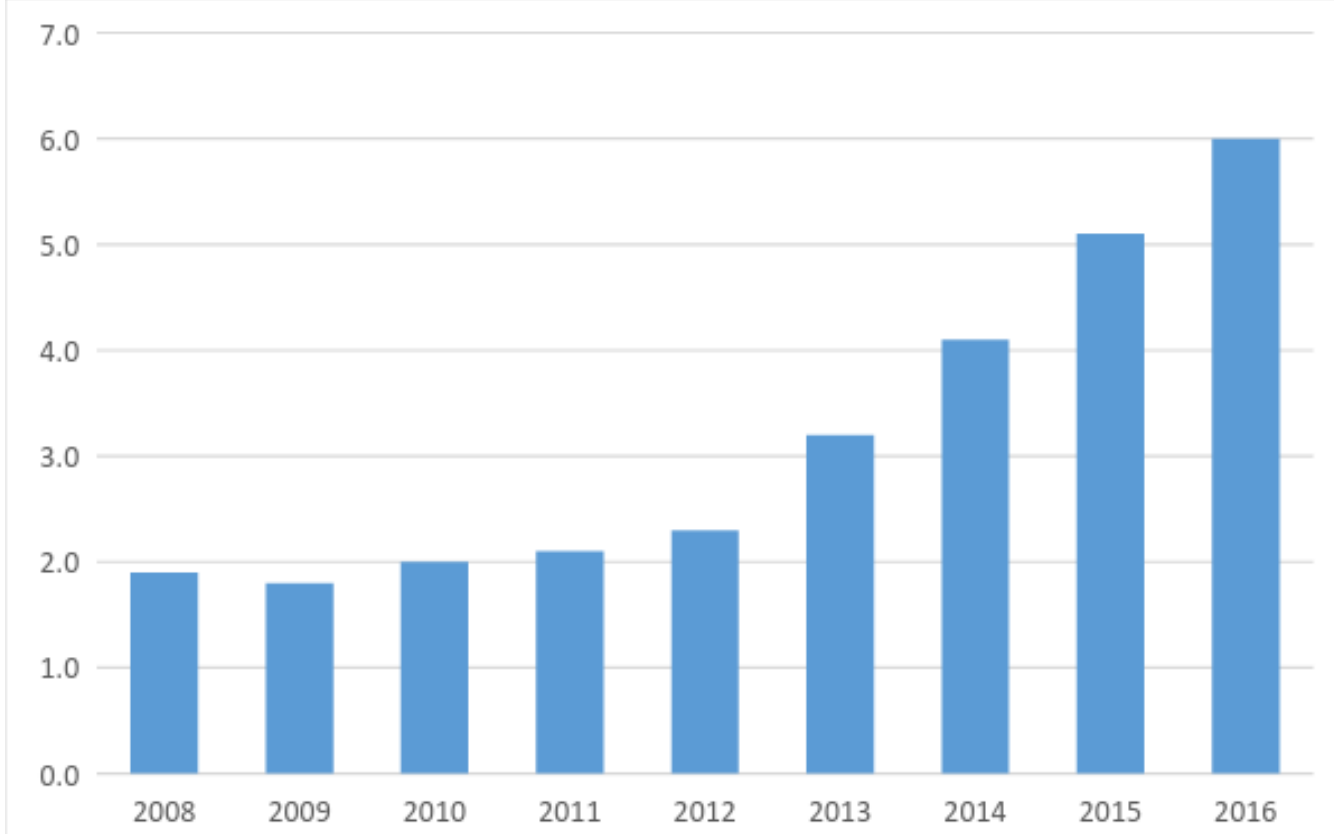

Rys. 1. Wartość pożyczek udzielonych ogółem w latach 2008 - 2016 w mld zł Źródło: Opracowanie własne na podstawie http://zfp.org.pl

Wartość portfela udzielonych pożyczek w latach 2008 - 2010 utrzymywała się na poziomie 1,5 - 1,7 mld zł. W 2012 roku wartość portfela udzielonych pożyczek wyniosła 
2,5 mld zł w porównaniu do 6,5 mld zł w 2016 roku, odnotowując 260,0\% wzrostu w ciągu 4 lat

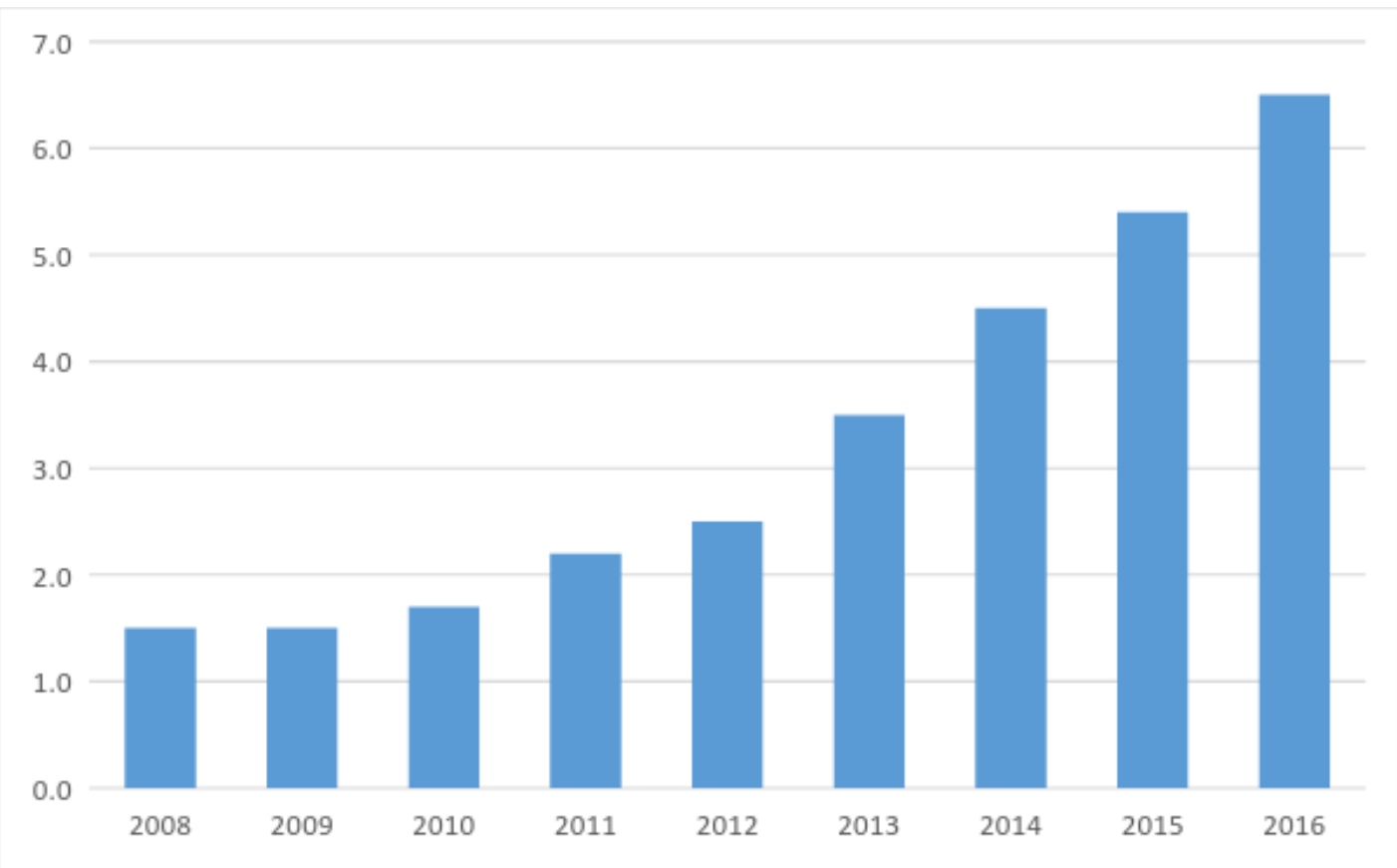

Rys. 2. Wartość portfela udzielonych pożyczek ogółem w mld zł Źródło: Opracowanie własne na podstawie http://zfp.org.pl

Szacuje się, że na koniec 2015 roku z usług spółek pożyczkowych w Polsce korzystało między 2,4 mln, a 3,5 mln klientów. Zgodnie z danymi pochodzącymi z:

- Narodowego Banku Polskiego (http://www.nbp.pl) z poza bankowego kredytu konsumenckiego w 2015 roku skorzystało 3,2 mln klientów,

- Biura Informacji Kredytowej (https://www.bik.pl) z poza bankowego kredytu konsumenckiego w 2015 roku skorzystało 2,4 - 3,5 mln klientów,

- Związku Firm Pożyczkowych (http://zfp.org.pl) z poza bankowego kredytu konsumenckiego w 2015 roku skorzystało 2,8 mln klientów(Bartosiewicz, 2018 ss. 714-729).

W trakcie 2015 roku na rynku pożyczek poza bankowych w Polsce działało ponad 100 firm oferujących kredyty konsumenckie. Pięć największych, czyli Provident, ProfiCredit, Vivus, Kredyt-Chwilówki oraz Bocian osiągnęły 83\% wszystkich przychodów wygenerowanych przez rynek pożyczek poza bankowych, osiągając odpowiednio 1,5 mld zł przychodu (48\%), 0,4 mld zł przychodu (13\%), 0,4 mld zł przychodu (13\%), 0,2 mld zł 
przychodu $(6 \%)$ oraz $0,1 \mathrm{mld}$ zł przychodu (3\%). Łączne przychody rynku pożyczek poza bankowych za 2015 rok wyniosły 3,1 mld zł (http://www.nwai.pl).

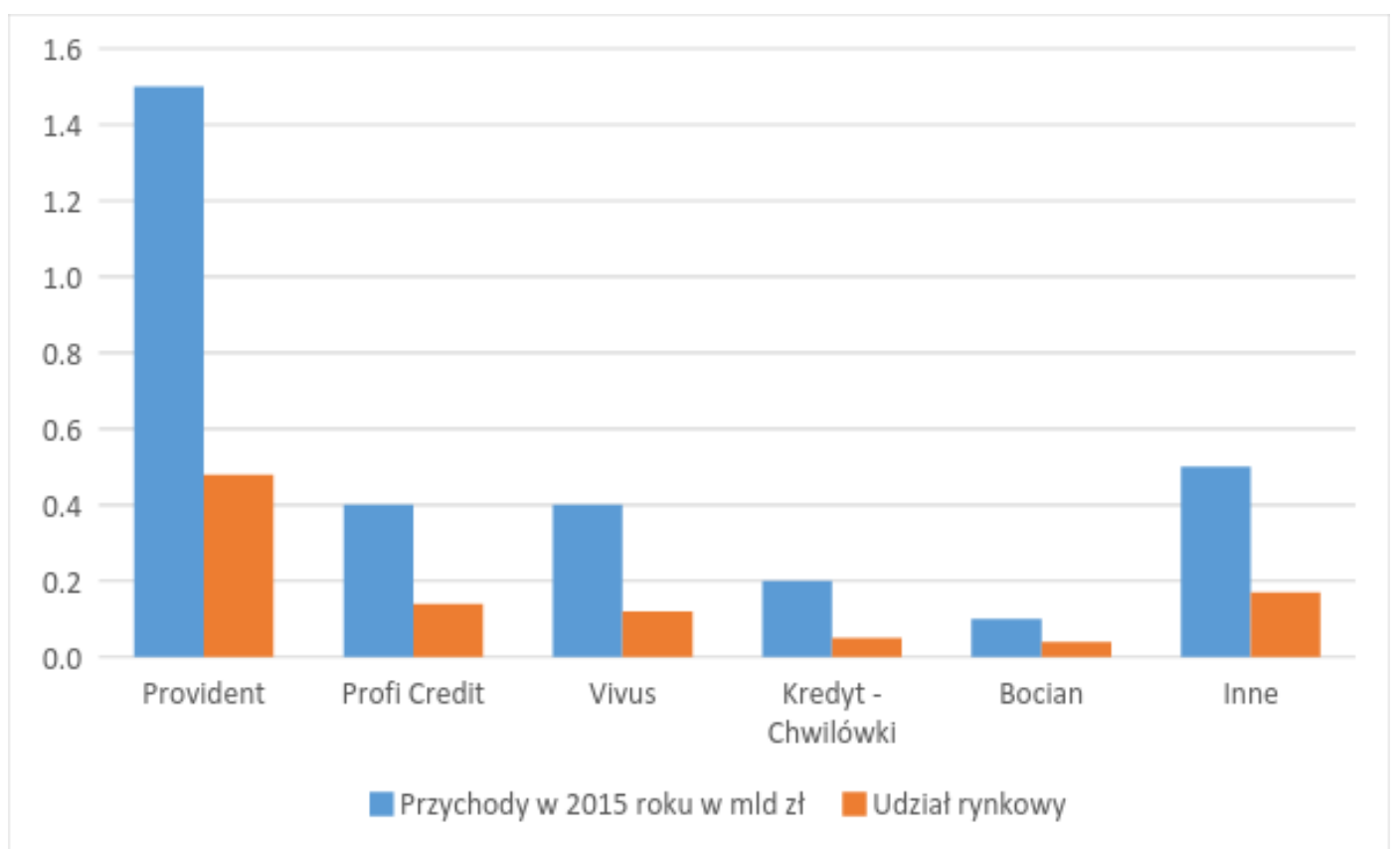

Rys. 3. Przychody osiągane przez 5 największych podmiotów udzielających pożyczek poza bankowych w 2015 roku wraz z ich udziałem w rynku.

Źródło: Opracowanie własne na podstawie http://www.nwai.pl

$\mathrm{Na}$ Polskim rynku pożyczek poza bankowych dominują trzy główne modele biznesowe (http://www.nwai.pl ) (Kochański, Kurasiński, 2018 ss. 344-354)

- domowy - proces pozyskania klienta odbywa się za pośrednictwem rozbudowanej sieci agentów, wspieranej intensywnymi działaniami marketingowymi,

- oddziałowy - zawarcie umowy najczęściej wymaga wizyty klienta w placówce firmy oraz dostarczenia wszystkich wymaganych dokumentów,

- internetowy - osoby korzystające z usług firm internetowych kierują się przede wszystkim prostotą i szybkością uzyskania decyzji kredytowej. Proces przyznania pożyczki trwa od kilku do kilkudziesięciu minut od momentu złożenia przez klienta wniosku.

2. OBOWIĄZUJĄCE PRZEPISY PRAWNE NAKLADAJĄCE OGRANICZENIA NA RENTOWNOŚĆ SPÓŁEK POŻYCZKOWYCH (Kochański, Kurasiński, 2018 ss. 355-371) 
Ustawa o kredycie konsumenckim z dnia 11 marca 2016 roku („Ustawa”), na podstawie której spółki pożyczkowe są zobowiązane działać, definiuje następujące ograniczenia:

- rozdział 3 art. 36a definiuje maksymalny poziom wysokości poza odsetkowych kosztów kredytu (,prowizja”) według wzoru:

$$
C A P=\left(25 \%+30 \% * \frac{T}{N}\right) * K
$$

gdzie:

CAP -maksymalną wysokość poza odsetkowych kosztów pożyczki,

$\mathrm{T}$ - okres, na jaki pożyczka jest brana $\mathrm{w}$ dniach,

$\mathrm{N}$ - liczba dnia w roku,

$\mathrm{K}$ - kapitał udzielonej pożyczki.

- rozdział 3 art. 36a określa, że poza odsetkowe koszty pożyczki w całym okresie kredytowania nie mogą być wyższe od całkowitej kwoty pożyczki, czyli przekroczyć 100\%. Oznacza to, że dla pożyczek trwających więcej niż 30 miesięcy, spółka nie może po 30stym miesiącu pobierać już żadnych dodatkowych prowizji (przy założeniu, że we wcześniejszych okresach pobierała maksymalne poziomy prowizji). Wartości prowizji maksymalnych w zależności o czasy trwania umowy pożyczki przedstawiono na wykresie 4 (Borucka, 2018, ss. 85-97),

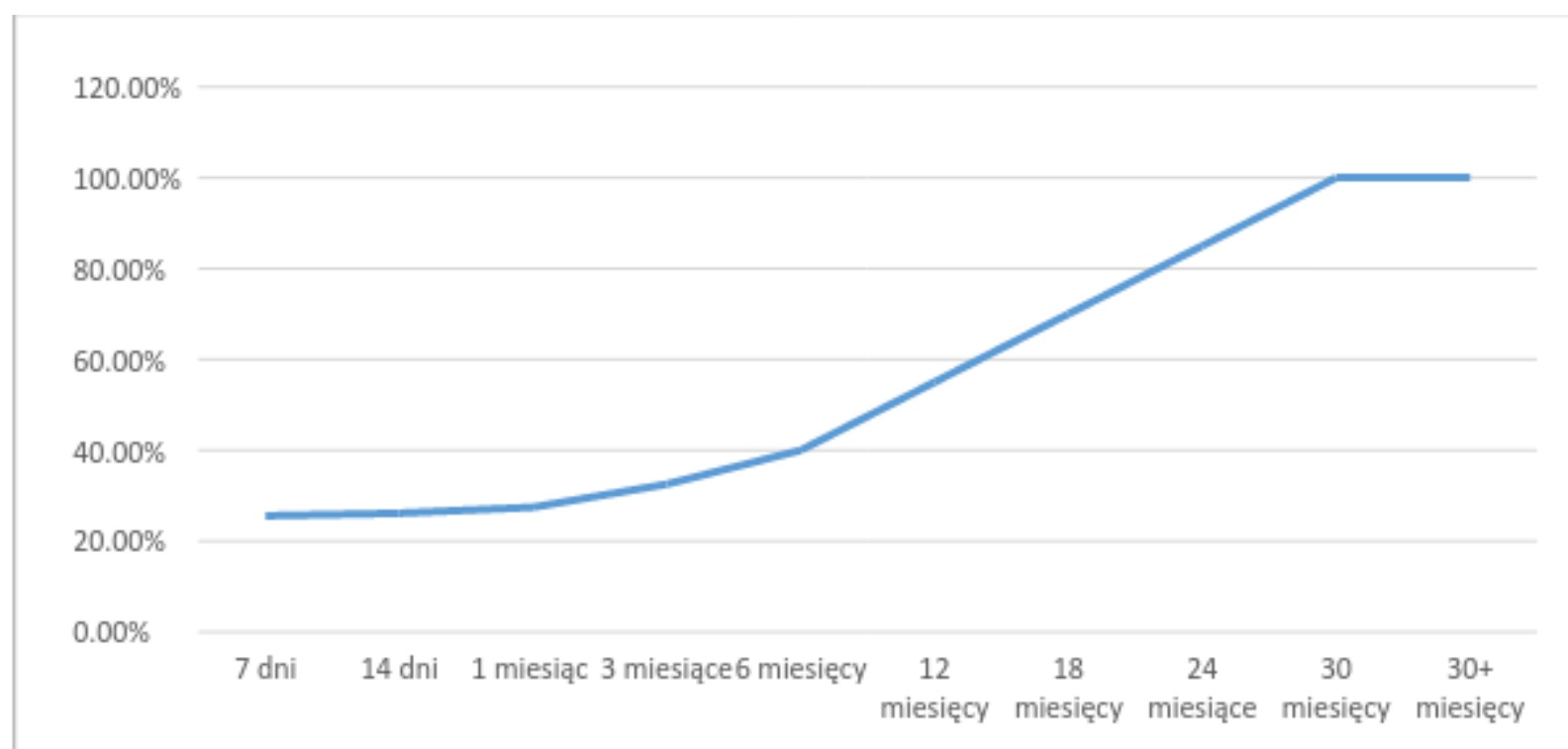

Rys. 4. Maksymalny limit kosztów poza odsetkowych jakie mogą być pobierane przez spółki pożyczkowe (Bartosiewicz, 2018, ss. 55-70). 
Źródło: Opracowanie własne na podstawie Ustawy o kredycie konsumenckim

- rozdział 3 art. $36 \mathrm{~b}$ definiuje, że w przypadku odroczenia spłaty zadłużenia wynikającego z umowy o kredyt konsumencki w okresie 120 dni od dnia wypłaty tego kredytu:

1) całkowitą kwotę kredytu dla celów ustalenia maksymalnej wysokości poza odsetkowych kosztów kredytu stanowi kwota udzielonego i wypłaconego kredytu, którego spłata została następnie odroczona,

2) do poza odsetkowych kosztów kredytu dolicza się wszystkie koszty i opłaty, które kredytobiorca jest obowiązany ponieść w związku z odroczeniem spłaty kredytu, naliczone w okresie 120 dni od dnia wypłaty kredytu.

- rozdział 3 art. 36c definiuje, że w przypadku udzielenia przez kredytodawcę konsumentowi, który nie dokonał pełnej spłaty kredytu, kolejnych kredytów w okresie 120 dni od dnia wypłaty pierwszego z kredytów:

1) całkowitą kwotę kredytu, dla celów ustalenia maksymalnej wysokości poza odsetkowych kosztów kredytu stanowi kwota pierwszego z kredytów,

2) poza odsetkowe koszty kredytu obejmują sumę poza odsetkowych kosztów wszystkich kredytów udzielonych w tym okresie,

- rozdział 5a art. 59a definiuje, że instytucje pożyczkowe mogą prowadzić działalność wyłącznie w formie spółki z ograniczoną odpowiedzialnością albo spółki akcyjnej. Ponadto, minimalny kapitał zakładowy instytucji pożyczkowej nie może wynosić mniej niż 200000 zł.

Interpretacja powyższych zapisów wskazuje, że jeżeli spółka pożyczkowa udzieli kredyt konsumencki na przykładowy okres 30 dni, jest uprawniona do pobrania poza odsetkowych kosztów w wysokości 27,46\% udzielonego kapitału. Jeżeli spółka pożyczkowa chciałaby odroczyć termin spłaty pożyczki w trakcie 120 dni od jej udzielenia nie jest uprawniona do pobierania większych prowizji niż te wynikające z art. 36a Ustawy. Jeżeli spółka pożyczkowa chciałaby udzielić klientowi kolejnej pożyczki w ciągu 120 dni od udzielenia pierwszej pożyczki, a pierwsza pożyczka została niespłacona, prowizje mogą być naliczane jedynie od kapitału pierwszej pożyczki. W tabeli 1 przedstawiono przykładowe wyliczenie maksymalnej prowizji dla pierwszej pożyczki o nominale 1.000 zł, przedłużenia pożyczki oraz drugiej pożyczki o nominale 2.000 zł.( Bartosiewicz, 2018, ss. 20-38) 
Tabela 1. Interpretacja art. 36 Ustawy na przykładach liczbowych

\begin{tabular}{|c|c|c|c|c|}
\hline & $\begin{array}{l}\text { Kapital } \\
\text { pożyczki } \\
(\text { PLN) }\end{array}$ & $\begin{array}{l}\text { Okres } \\
\text { pożyczki } \\
\text { (dni) }\end{array}$ & $\begin{array}{l}\text { Maksymalna } \\
\text { prowizja zgodnie } \\
\text { ze wzorem (1) }\end{array}$ & $\begin{array}{l}\text { Kwota } \\
\text { prowizji } \\
\text { (PLN) }\end{array}$ \\
\hline Pierwsza pożyczka & 1000 & 30 & $27,46 \%$ & 274,59 \\
\hline $\begin{array}{l}\text { Druga pożyczka (w przypadku } \\
\text { udzielenia w ciągu } 120 \text { dni od } \\
\text { udzielenia pierwszej gdy } \\
\text { pierwsza niespłacona) }\end{array}$ & 2000 & 30 & $0 \%$ & 0,00 \\
\hline $\begin{array}{l}\text { Druga pożyczka (w przypadku } \\
\text { udzielenia po } 120 \text { dniach od } \\
\text { udzielenia pierwszej gdy } \\
\text { pierwsza niespłacona) }\end{array}$ & 2000 & 30 & $27,46 \%$ & 549,18 \\
\hline $\begin{array}{l}\text { Przedłużenie pierwszej } \\
\text { pożyczki o kolejne } 30 \text { dni (w } \\
\text { przypadku gdy nie minęło } 120 \\
\text { dni od udzielenia pierwszej } \\
\text { pożyczki) }\end{array}$ & 1000 & 60 & $2,46 \%$ & 24,59 \\
\hline $\begin{array}{l}\text { Przedłużenie pierwszej } \\
\text { pożyczki o kolejne } 30 \mathrm{dni}(\mathrm{w} \\
\text { przypadku gdy minęło } 120 \mathrm{dni} \\
\text { od udzielenia pierwszej } \\
\text { pożyczki) }\end{array}$ & 1000 & 30 & $27,46 \%$ & 274,59 \\
\hline
\end{tabular}

Źródło: Opracowanie własne

\section{ROZWIĄZANIA STOSOWANE PRZEZ SPÓŁKI POŻYCZKOWE W CELU OPTYMALIZACJI ZYSKU PRZY OBOWIĄZUJĄCYCH OGRANICZENIACH PRAWNYCH}

W związku z opisanymi w poprzedniej części artykułu ograniczeniami w wysokościach pobieranych maksymalnych prowizji oraz przedziałami czasowymi pozwalającymi na pobranie prowizji po raz kolejny, zostały podjęte przez spółki pożyczkowe działania w celu możliwie jak najefektywniejszego wykorzystania dostępnych limitów. Jednym z najefektywniejszych prowizyjnie stosowanych przez sektor poza bankowy rozwiązań jest refinansowanie. Modeli refinansowania można zidentyfikować kilka, miedzy innymi: (Waśniewski T., Kozicki B, Brzeziński M., Warszawa 2017, ss. 146-156)

1. 2 spółki pożyczkowe oraz pośrednik pożyczkowy (w tym netto i brutto),

2. 4 spółki pożyczkowe bez pośrednika (w tym netto i brutto),

3. 2 spółki pożyczkowe bez pośrednika (w tym netto i brutto).

$\mathrm{W}$ artykule tym opisano schemat nr 2. 


\subsection{Refinansowanie netto}

Refinansowanie netto polega na refinansowaniu wyłącznie kwoty udzielonego kapitału, czyli klient jest zobowiązany do pokrycia kosztów prowizyjnych nim będzie mógł skorzystać $\mathrm{z}$ usługi refinansowania.

W celu jego realizacji, działalność pożyczkowa w Polsce musi być prowadzona przez wiele spółek, które refinansują klientowi pożyczkę między sobą. W tabeli 2 przedstawiono refinansowanie dla pożyczki 30 dniowej i przykładowej kwoty pożyczki 1.000 zł. Przy tych założeniach, spółka A udziela klientowi pożyczki na 1.000 zł i ma możliwość pobrania prowizji 27,46\%, zgodnie ze wzorem (1). Następnie, po 30 dniach pożyczka jest odkupywana od spółki A przez spółkę B. Jako że jest to pierwsza pożyczka spółki B wobec tego klienta w przedziale 120 dni, spółka B ma prawo pobrać ponownie pełną prowizję 27,46\%. Następnie, po kolejnych 30 dniach pożyczka jest odkupywana od spółki B przez spółkę C. W związku z faktem, że jest to pierwsza pożyczka spółki C wobec tego klienta w przedziale 120 dni, spółka C ma prawo pobrać ponownie pełną prowizję 27,46\%. Następnie, po kolejnych 30 dniach pożyczka jest odkupywana od spółki C przez spółkę D. Jako że jest to pierwsza pożyczka spółki D wobec tego klienta w przedziale 120 dni, spółka D ma prawo pobrać ponownie pełną prowizję 27,46\%. Następnie, w związku z faktem że minęło już łącznie 120 dni od momentu kiedy spółka A udzieliła pierwszej pożyczki klientowi, ma ona prawo udzielić drugiej pożyczki i pobrać kolejny raz pełną prowizję, w związku z czym pożyczka jest odkupywana od spółki D przez spółkę A. Cykl ten można powtarzać w nieskończoność lub do momentu kiedy klient podejmie decyzję o spłacie pożyczki.( Stępień K. Furman W., Oleksiewicz I., Warszawa 2017)

W efekcie stosowania refinansowania netto spółki A, B, C i D generują łącznie w ciągu 120 dni trwania pożyczki 109,84\% prowizji czyli dla nominału 1.000 zł oznacza to prowizję w kwocie 1.098,36 zł. Dla porównania, przy udzielaniu pożyczki od razu na 120 dni, działając za pośrednictwem jednej spółki i stosując wprost zapisy Ustawy, spółka mogłaby pobrać 34,84\% prowizji czyli 348,36 zł.

Tabela 2. Porównanie prowizji osiąganych w przypadku stosowania refinansowania netto oraz w przypadku braku refinansowania netto

\begin{tabular}{|c|c|c|c|c|c|c|}
\hline & $\begin{array}{c}\text { Kapital } \\
\text { pożyczki } \\
\text { (PLN) }\end{array}$ & $\begin{array}{c}\text { Okres } \\
\text { pożyczki } \\
\text { (dni) }\end{array}$ & $\begin{array}{c}\text { Maksymalna } \\
\text { prowizja } \\
\text { zgodnie ze } \\
\text { wzorem (1) }\end{array}$ & $\begin{array}{c}\text { Maksymalna } \\
\text { prowizji } \\
\text { (PLN) }\end{array}$ & $\begin{array}{c}\text { prowizja } \\
\text { stosując } \\
\text { wrost zapisy } \\
\text { Ustawy i } \\
\text { prowadząc } \\
\text { dzialalność za }\end{array}$ & $\begin{array}{c}\text { Kwota } \\
\text { prowizji } \\
\text { (PLN) }\end{array}$ \\
\hline
\end{tabular}




\begin{tabular}{|c|c|c|c|c|c|c|}
\hline & & & & & $\begin{array}{l}\text { pośrednictwem } \\
\text { jednej spółki }\end{array}$ & \\
\hline $\begin{array}{l}\text { Pierwsza } \\
\text { pożyczka } \\
\text { udzielona } \\
\text { przez } \\
\text { Spółkę A } \\
\text { (od } 1 \text { do } \\
30 \text { dnia) } \\
\end{array}$ & 1000 & 30 & $27,46 \%$ & 274,59 & $27,46 \%$ & 274,59 \\
\hline $\begin{array}{l}\text { Pierwsza } \\
\text { pożyczka } \\
\text { udzielona } \\
\text { przez } \\
\text { Spółkę B } \\
\text { (od } 31 \text { do } \\
60 \text { dnia) }\end{array}$ & 1000 & 30 & $27,46 \%$ & 274,59 & $2,46 \%$ & 24,59 \\
\hline $\begin{array}{l}\text { Pierwsza } \\
\text { pożyczka } \\
\text { udzielona } \\
\text { przez } \\
\text { Spółkę C } \\
\text { (od } 61 \text { do } \\
90 \text { dnia) }\end{array}$ & 1000 & 30 & $27,46 \%$ & 274,59 & $2,46 \%$ & 24,59 \\
\hline $\begin{array}{l}\text { Pierwsza } \\
\text { pożyczka } \\
\text { udzielona } \\
\text { przez } \\
\text { Spółkę D } \\
\text { (od } 91 \text { do } \\
120 \text { dnia) }\end{array}$ & 1000 & 30 & $27,46 \%$ & 274,59 & $2,46 \%$ & 24,59 \\
\hline $\begin{array}{l}\text { Druga } \\
\text { pożyczka } \\
\text { udzielona } \\
\text { przez } \\
\text { Spółkę A } \\
\text { (od } 121 \text { do } \\
150 \text { dnia) }\end{array}$ & 1000 & 30 & $27,46 \%$ & 274,59 & $27,46 \%$ & 274,59 \\
\hline $\begin{array}{l}\text { Pierwsza } \\
\text { pożyczka } \\
\text { udzielona } \\
\text { przez } \\
\text { Spółkę B } \\
\text { (od } 151 \text { do } \\
180 \text { dnia) } \\
\end{array}$ & 1000 & 30 & $27,46 \%$ & 274,59 & $2,46 \%$ & 24,59 \\
\hline $\begin{array}{l}\text { Pierwsza } \\
\text { pożyczka }\end{array}$ & 1000 & 30 & $27,46 \%$ & 274,59 & $2,46 \%$ & 24,59 \\
\hline
\end{tabular}




\begin{tabular}{|l|l|l|l|l|l|l|}
\hline $\begin{array}{l}\text { udzielona } \\
\text { przez } \\
\text { Spółkę C } \\
\text { (od 181 do } \\
210 \text { dnia) }\end{array}$ & & & & & \\
\hline $\begin{array}{l}\text { Pierwsza } \\
\text { pożyczka } \\
\text { udzielona } \\
\text { przez } \\
\text { Spółkę D } \\
\text { (od 211 do } \\
240 \text { dnia) }\end{array}$ & 1000 & 30 & $27,46 \%$ & 274,59 & $2,46 \%$ & 24,59 \\
\hline Razem & $\mathbf{n / a}$ & $\mathbf{2 4 0}$ & $\mathbf{2 1 9 , 6 7 \%}$ & $\mathbf{2 ~ 1 9 6 , 7 2}$ & $\mathbf{6 9 , 6 7 \%}$ & $\mathbf{6 9 6 , 7 2}$ \\
\hline
\end{tabular}

Źródło: Opracowanie własne

\subsection{Refinansowanie brutto}

Refinansowanie brutto polega na odsprzedaży pomiędzy spółkami całego długu klienta, łącznie z narosłymi i niezapłaconymi prowizjami. Poza tym elementem, cały schemat transakcji przebiega identycznie jak przy refinansowaniu netto (Kozicki B., Tomaszewski J., Brzeziński M., Waściński Z, Warszawa 2018, ss.322-343)

W efekcie stosowania refinansowania brutto spółki A, B, C i D generują łącznie w ciągu 120 dni trwania pożyczki 109,84\% prowizji czyli dla nominału pierwszej pożyczki $1.000 \mathrm{zł}$ oznacza to prowizję w kwocie 1.639,26zł. Dla porównania, przy udzielaniu pożyczki od razu na 120 dni, działając za pośrednictwem jednej spółki i stosując wprost zapisy Ustawy, spółka mogłaby pobrać 34,84\% prowizji czyli 348,36 zł. (Zelkowski J., Kijek M., Teklińska D., Zaborowicz- Malcherczyk O.,Warszawa 2018, ss. 306-316)

Tabela 3. Porównanie prowizji osiąganych w przypadku stosowania refinansowania brutto oraz w przypadku braku refinansowania brutto

\begin{tabular}{|l|c|c|c|c|c|c|}
\hline & $\begin{array}{c}\text { Kapital } \\
\text { pożyczki } \\
\text { (PLN) }\end{array}$ & $\begin{array}{c}\text { Okres } \\
\text { pożyczki } \\
\text { (dni) }\end{array}$ & $\begin{array}{c}\text { Maksymalna } \\
\text { prowizja } \\
\text { zgodnie ze } \\
\text { wzorem (1) }\end{array}$ & $\begin{array}{c}\text { Maksymalna } \\
\text { Krowota } \\
\text { prowizja } \\
\text { (PLN) } \\
\text { stosując wprost } \\
\text { zapisy Ustawy i } \\
\text { prowadząc } \\
\text { działalność za } \\
\text { pośrednictwem } \\
\text { jednej spółki }\end{array}$ & $\begin{array}{c}\text { Kwota } \\
\text { prowizji } \\
\text { (PLN) }\end{array}$ & \\
\hline $\begin{array}{l}\text { Pierwsza } \\
\text { pożyczka } \\
\text { udzielona } \\
\text { przez } \\
\text { Spółkę A }\end{array}$ & 1000 & 30 & $27,46 \%$ & 274,59 & $27,46 \%$ & 274,59 \\
\hline
\end{tabular}


Systemy Logistyczne Wojsk nr 49/2018

\begin{tabular}{|c|c|c|c|c|c|c|}
\hline $\begin{array}{l}\text { (od } 1 \text { do } \\
30 \text { dnia) }\end{array}$ & & & & & & \\
\hline $\begin{array}{l}\text { Pierwsza } \\
\text { pożyczka } \\
\text { udzielona } \\
\text { przez } \\
\text { Spółkę B } \\
\text { (od } 31 \text { do } \\
60 \text { dnia) }\end{array}$ & 1274,59 & 30 & $27,46 \%$ & 349,99 & $2,46 \%$ & 24,59 \\
\hline $\begin{array}{l}\text { Pierwsza } \\
\text { pożyczka } \\
\text { udzielona } \\
\text { przez } \\
\text { Spółkę C } \\
\text { (od } 61 \text { do } \\
90 \text { dnia) }\end{array}$ & 1624,58 & 30 & $27,46 \%$ & 446,09 & $2,46 \%$ & 24,59 \\
\hline $\begin{array}{l}\text { Pierwsza } \\
\text { pożyczka } \\
\text { udzielona } \\
\text { przez } \\
\text { Spółkę D } \\
\text { (od } 91 \text { do } \\
120 \text { dnia) }\end{array}$ & 2070,67 & 30 & $27,46 \%$ & 568,59 & $2,46 \%$ & 24,59 \\
\hline $\begin{array}{l}\text { Druga } \\
\text { pożyczka } \\
\text { udzielona } \\
\text { przez } \\
\text { Spółkę A } \\
\text { (od } 121 \\
\text { do } 150 \\
\text { dnia) }\end{array}$ & 2639,26 & 30 & $27,46 \%$ & 724,71 & $27,46 \%$ & 274,59 \\
\hline $\begin{array}{l}\text { Pierwsza } \\
\text { pożyczka } \\
\text { udzielona } \\
\text { przez } \\
\text { Spółkę B } \\
\text { (od } 151 \\
\text { do } 180 \\
\text { dnia) }\end{array}$ & 3363,98 & 30 & $27,46 \%$ & 923,71 & $2,46 \%$ & 24,59 \\
\hline $\begin{array}{l}\text { Pierwsza } \\
\text { pożyczka } \\
\text { udzielona } \\
\text { przez } \\
\text { Spółkę C } \\
\text { (od } 181 \\
\text { do } 210 \\
\text { dnia) }\end{array}$ & 4287,69 & 30 & $27,46 \%$ & 1177,36 & $2,46 \%$ & 24,59 \\
\hline $\begin{array}{l}\text { Pierwsza } \\
\text { pożyczka } \\
\text { udzielona }\end{array}$ & 5465,05 & 30 & $27,46 \%$ & 1500,65 & $2,46 \%$ & 24,59 \\
\hline
\end{tabular}




\begin{tabular}{|l|c|c|c|c|c|c|}
\hline $\begin{array}{l}\text { przez } \\
\text { Spółkę D } \\
\text { (od 211 }\end{array}$ & & & & & & \\
do 240 & & & & & & \\
dnia) & & & & & & \\
\hline Razem & n/a & $\mathbf{2 4 0}$ & $\mathbf{2 1 9 , 6 7 \%}$ & $\mathbf{5 9 6 5 , 7 0}$ & $\mathbf{6 9 , 6 7 \%}$ & $\mathbf{6 9 6 , 7 2}$ \\
\hline
\end{tabular}

Źródło: Opracowanie własne

Stosowanie refinansowania brutto jest bardziej dochodowe w porównaniu do refinansowania netto, jednak bardziej ryzykowne gdyż klient nie jest zobowiązany do zwrotu żadnych środków w dłuższym okresie czasu przy stale narastającym saldzie zadłużenia. (Waściński z., Bartosiewicz S, Warszawa 2018, ss. 39-54)

\section{PODSUMOWANIE}

Spółki pożyczkowe, pomimo nakładanych na nie ograniczeń prawnych m.in. limitowania maksymalnych wielkości prowizji, wykazują rok rocznie od 2010 roku dwucyfrowe procentowe wzrosty w wartości udzielanych pożyczek.

Stały wzrost popytu na produkty firm działających poza sektorem bankowym wynika głównie z:

- łatwości w dostępie do pożyczki - spółki stosują wszystkie modele biznesowe: domowy, oddziałowy i internetowy podczas gdy banki wciąż w większości opierają sprzedaż na modelu oddziałowym,

- szybkości przekazania środków klientowi - spółki pożyczkowe oferujące produkty online przelewają środki na konto klienta nawet w 15 minut od momentu gdy klient zgłosi się po pożyczkę, w porównaniu do minimum kilku dni w przypadku produktów bankowych,

- dostępności do produktu - firmy pożyczkowe udostępniają swoje produkty on-line również za pośrednictwem aplikacji mobilnych na telefon komórkowy,

- uproszczonej oceny zdolności kredytowej klienta - spółki pożyczkowe akceptują dochody klientów z innych form zatrudnienia niż umowy o pracę, akceptują również nie udokumentowane źródła dochodów,

- elastyczności firm pożyczkowych względem popytu zgłaszanego przez klientów, dostosowując swoją ofertę produktową do potrzeb rynku. Jest to zazwyczaj możliwe dzięki mniej złożonej strukturze decyzyjnej w porównaniu do banków. 
W efekcie, pomimo ograniczeń prawnych nakładanych na sektor poza bankowy, spółki pożyczkowe w każdym roku zdobywają nowych klientów, a dzięki kreatywnej interpretacji przepisów prawa i budowaniu złożonych struktur prowizyjnych, realizują wysokie zyski.

\section{LITERATURA}

1. Stańczyk, K.; Sektor finansów publicznych w Polsce, Ochrona konsumentów na rynku finansowym, Warszawa 2016 ISBN 978-83-7523-535-7

2. Bartosiewicz S., Funkcjonowanie małych przedsiębiorstw rodzinnych na rynku polskim, Gospodarka Materiałowa \& Logistyka 5/2018, Warszawa 2018, ISSN 12312037, ss. 714-729

3. Kochański T., Kurasiński Z, Model organizacji wirtualnej małych i średnich przedsiębiorców, Gospodarka Materiałowa \& Logistyka 5/2018, Warszawa 2018, ISSN 1231-2037, ss. 344-354

4. Kochański T., Kurasiński Z., Innowacyjność we współczesnym przedsiębiorstwie, Gospodarka Materiałowa \& Logistyka 5/2018, Warszawa 2018, ISSN 1231-2037, ss. 355-371

5. Borucka A., Ekonometryczne modelowanie popytu konsumpcyjnego na podstawie modelu Sarima, Gospodarka Materiałowa \& Logistyka 5/2018, Warszawa 2018, ISSN 1231-2037, ss. 85-97

6. Bartosiewicz S., Zarządzanie procesowe przedsiębiorstwem usługowym, Gospodarka Materiałowa \& Logistyka 5/2018, Warszawa 2018, ISSN 1231-2037, ss. 55-70

7. Bartosiewicz S., Nowoczesne technologie stosowane w systemie magazynowania przedsiębiorstwa produkcyjnego, Gospodarka Materiałowa \& Logistyka 5/2018, Warszawa 2018, ISSN 1231-2037, ss. 20-38

8. Stępień K. Furman W., Oleksiewicz I., Bezpieczeństwo finansowe w społeczeństwie informacyjnym, Warszawa 2017, ISBN 978-83-62751-65-5

9. Kozicki B., Tomaszewski J., Brzeziński M., Waściński Z., Zastosowanie prognozy do planowania przychodów przedsiębiorstwa, Gospodarka Materiałowa \& Logistyka 5/2018, Warszawa 2018, ISSN 1231-2037, ss. 332-343

10. Ślaski, P., Waśniewski, T.R. (2016). Zastosowanie dronów do inwentaryzacji magazynów otwartych wielkopowierzchniowych. Logistyka w XXI wieku, Wydawnictwo Społecznej Akademii Nauk. 
11. Waśniewski T. R., Ślaski P. Modelowanie procesu automatycznego rozpoznawania i identyfikowania pojazdów w oparciu o technologię RFID, Gospodarka Materiałowa i Logistyka, nr 5, 2018, PWE.

12. Waśniewski T. R., Ślaski P., Modelowanie procesu identyfikowalności wyrobów za pomocą technologii RFID, Gospodarka Materiałowa i Logistyka, nr 5, 2018,PWE.

13. Waśniewski T.R., Laskowski, D., ,Wirtualne sterowanie magazynami, Systemy Logistyczne Wojsk nr 44,2016,WAT

14. Waśniewski T. R.; Ignaciuk P., Osowski, R. ,RFID to use customers of service, Systemy Logistyczne Wojsk nr 46, 2017, WAT

15. Waśniewski T. R, Krupnik D, Sustainability of urban transportation main developments, TRANSPORT MEANS 2017,3,2017,KAUNAS UNIVERSITY OF TECHNOLOGY

16. Waściński z., Bartosiewicz S., Wybór dostawcy dla małego przedsiębiorstwa metodą analytical hierarchy proces, Warszawa 2018, Gospodarka Materiałowa \& Logistyka 5/2018, Warszawa 2018, ISSN 1231-2037, ss. 39-54

17. Waściński, T. , Dudkowska, A.; Ochrona konsumentów na rynku finansowym, Systemy Logistyczne Wojsk, Warszawa, 2017. ISSN 1508-5430

18. Zelkowski J., Kijek M., Teklińska D., Zaborowicz- Malcherczyk O., Modelowanie funkcjonowania gospodarki magazynowej w przedsiębiorstwie $\mathrm{x}$, Gospodarka Materiałowa \& Logistyka 5/2018, Warszawa 2018, ISSN 1231-2037, ss. 306-316

19. https://www.bik.pl

20. http://zfp.org.pl

21. http://www.nbp.pl

22. http://www.nwai.pl

23. https://www.knf.gov.pl

24. Ustawa o kredycie konsumenckim z dnia 23 sierpnia 2016 r. (Dz. U. z 2016 r. poz. 1528) 